\title{
First record of the non-native green palpworm Marenzelleria viridis (Annelida: Spionidae) in the Clyde Estuary
}

\author{
M. O’Reilly ${ }^{1} \&$ S. Nowacki \\ ${ }^{1,2}$ Scottish Environment Protection Agency, Angus Smith Building, 6 Parklands Avenue, Eurocentral, Holytown, North \\ Lanarkshire ML1 4WQ \\ E-mail: myles.oreilly@sepa.org.uk
}

\begin{abstract}
The non-native polychaete worm Marenzelleria viridis (Verrill, 1873) was found for the first time in the upper Clyde Estuary in 2016. This represents the first occurrence of this alien species on the west coast of Scotland. It appears to be well established in low salinity waters at Govan Wharf where it dominated the biomass of riverbed infaunal invertebrates with densities of around 1,300 worms $\mathrm{m}^{-2}$.
\end{abstract}

\section{INTRODUCTION}

The Spionidae is a large family of benthic tube-dwelling polychaete worms from marine or estuarine waters. They possess a pair of long cephalic feeding palps and a row of gills on either side of the body, commencing in the anterior region and continuing posteriorly to varying degrees in different species (Fauchald, 1977). The green palpworm Marenzelleria viridis (Verrill, 1873) is a spionid species native to the north-eastern coast of North America and is often abundant in low salinity estuarine waters (Maciolek, 1984). It was first found in European waters in 1982 in the upper Forth Estuary, Scotland (Elliott \& Kingston, 1987) and subsequently in the Tay Estuary, Scotland in 1984 (Atkins et al., 1987). Since then it has spread throughout the North Sea and into the low salinity waters of the Baltic Sea (Gruszka, 1991; Essink \& Kleef, 1993; Kube et al., 1996). However, investigations revealed major differences between the North Sea and Baltic populations indicating that two separate species may be present (Bastrop et al., 1995). There has also been some confusion regarding the possible occurrence in the North Sea of a sibling species from the Arctic, Marenzelleria wireni Augener, 1913, which, according to Maciolek (1984), is very similar to M. viridis, differing only in subtle respects.

The genus Marenzelleria was reviewed by Sikorski \& Bick (2004) who established a new species M. neglecta for the Baltic material, although recognising that this too was an alien species that originally came from North America. They provided full descriptions of all four known Marenzelleria species, plus a provisional description (based on limited material) of another potential new species from North Carolina. They also provided a morphometric table of the diagnostic features for each of the species (for specimens at different sizes) and a simple dichotomous key for specimens more than
$1 \mathrm{~mm}$ wide. They regarded $M$. wireni as restricted to Arctic waters, where it co-occurred with M. arctia, and considered most North Sea Marenzelleria material to be $M$. viridis, although both $M$. viridis and $M$. neglecta were recorded in the Elbe Estuary. Subsequently, Bick (2005) provided a full description of the new species from North Carolina and an updated dichotomous key for all five species.

In a further study of Marenzelleria material from the Baltic Sea, Bastrop \& Blank (2006) used DNA markers to help distinguish species and found both $M$. viridis and M. neglecta were present in the western Baltic Sea, and also discovered that the arctic species, M. arctia had invaded the Gulf of Bothnia in the northern Baltic Sea. More recently, M. neglecta has invaded the Sea of Azov (Syomin et al., 2017). The arrival of various Marenzelleria species in low salinity waters throughout Europe, where they may become abundant, has spawned numerous studies of their invasion biology and ecological impact (e.g. McLusky et al., 1993; Kotta et al., 2003, 2006; Van Moorsel et al., 2010; Maximov, 2011; Michalek \& Werner, 2012).

In British waters, records for $M$. viridis are summarised in the National Biodiversity Network (NBN) Atlas (National Biodiversity Network, 2019) and include records from the Beauly Firth, the Tay Estuary, the Forth Estuary (all Scotland), Berwick-upon-Tweed, the Tyne Estuary, the Humber Estuary, the Thames Estuary (all England) and in Northern Ireland from the Foyle Estuary and the Bann Estuary. Records of M. wireni in the Forth and Milford Haven in the NBN Atlas have probably been misidentified and are most likely to have been $M$. viridis. There are no records of $M$. neglecta in British waters, and $M$. viridis remains the only confirmed species in this region.

\section{CLYDE ESTUARY SURVEY METHODS}

In 2016 a small survey was undertaken in the upper Clyde Estuary, Scotland to provide some ecological data in relation to planned sewerage system works in the local vicinity. The survey was carried out on 3rd August 2016 and repeated on 6th September 2016 and 7th December 2016. Sampling of the river bed sediment was undertaken at three locations in Glasgow: upstream of Shieldhall Sewage Treatment Works (NS5420966394), 
Govan Wharf (NS5542966014), and upstream of Kelvin Confluence (NS5583065839) all of which have depths of around $8 \mathrm{~m}$. A single $0.1 \mathrm{~m}^{2}$ Day Grab for biological assessment (and accompanying grab for particle size determination) were collected at the three sites. The biology grabs were washed on a $0.5 \mathrm{~mm}$ mesh sieve to remove fine sediments and the sieve residue transferred into a bucket, fixed with formaldehyde and returned to the Scottish Environment Protection Agency (SEPA) laboratory. The preserved biological samples were subsequently rinsed with water and contained fauna was picked out, identified and counted. The fauna was identified with the aid of standard keys (e.g. Hayward \& Ryland, 2017). Subsequently the invertebrate specimens were preserved in methylated spirit and stored.

\section{SURVEY FINDINGS}

The macrofaunal invertebrates in the Clyde Estuary samples comprised mostly oligochaete and polychaete worms, with much smaller numbers of crustaceans, molluscs, and insect larvae (Table 1). The sediment near Shieldhall was muddy with leaf debris and supported a diverse and abundant fauna - but only in August. At Govan Wharf the sediment was muddy grit and had a diverse and abundant fauna on all three samplings. The sediment close to the Kelvin Confluence was undecomposed leaf litter and supported little or no invertebrate fauna.

The benthic fauna abundance was dominated by oligochaete worms (Baltidrilus costatus, Tubificoides benedii, T. pseudogaster, unidentified tubificid sp., Nais sp., Paranais litoralis and Lumbricillus sp.), which characterise low salinity estuarine sediments laden with riverine detritus.
The polychaetes were generally much less numerous and included the estuarine ragworm Hediste diversicolor, and the spionids Polydora cornuta and Streblospio shrubsolii. However, the non-native green palpworm was found to be present at Govan Wharf, with relatively high numbers (142 - 156 per grab sample) on each sampling occasion, and with a single specimen also found at Shieldhall in August. M. viridis are relatively large worms, around $3-5 \mathrm{~cm}$ long, and were easily visible during the field sampling among the sediment residue on the sieve. They have a pale green colouration with distinct rows of red gills (Fig. 1). The ragworm $H$. diversicolor is similarly sized and coloured but lacks the red gills. The colouration in M. viridis is retained following fixation with formaldehyde but fades quickly once specimens are transferred to alcohol preservative. The characteristic feeding palps are invariably shed during sample processing and fixation (Fig. 1). The specific identity for the $M$. viridis specimens was confirmed morphologically using the key in Bick (2005). The Clyde specimens had over 60 segments with gills extending up to two-thirds of their body length, nuchal organs reaching the end of segment 2, and fewer than 15 segments between the appearance of the dorsal and ventral hooded hooks, all characteristic of M. viridis.

Only a few arthropods were found in the samples, including the brown shrimp Crangon crangon, amphipod shrimps of the genus Gammarus, and a chironomid midge larva. Molluscs were represented by one gastropod - the non-native Jenkin's spire snail (Potamopyrgus antipodarum), and a few juvenile Baltic tellin (Limecola balthica).

\begin{tabular}{|c|c|c|c|c|c|c|c|c|c|}
\hline \multirow[t]{2}{*}{ Fauna } & \multicolumn{3}{|c|}{ Shieldhall } & \multicolumn{3}{|c|}{ Govan } & \multicolumn{3}{|c|}{ Kelvin } \\
\hline & $\overline{\text { Aug. }}$ & Sep. & Dec. & Aug. & Sep. & Dec. & $\overline{\text { Aug. }}$ & Sep. & Dec. \\
\hline Hediste diversicolor & 4 & & & 2 & 2 & 3 & & & \\
\hline Marenzelleria viridis & 1 & & & 142 & 142 & 156 & & & \\
\hline Polydora cornuta & 1 & & & 4 & & & & & \\
\hline Streblospio shrubsolii & 3 & & & 1 & 2 & & & & \\
\hline Baltidrilus costatus & 193 & 2 & & 101 & 26 & 83 & 4 & & \\
\hline Tubificoides benedii & 15 & & 1 & & & & & & \\
\hline Tubificoides pseudogaster & 51 & 1 & & 63 & 4 & & & & \\
\hline Tubificid sp. & 146 & 4 & & 275 & 194 & 83 & 1 & & \\
\hline Nais sp. & 74 & & & 14 & & & & & \\
\hline Paranais litoralis & 454 & & & 90 & & 2 & & & \\
\hline Lumbricillus sp. & & & & & 2 & & & & \\
\hline Gammarus sp. & & & & 7 & & & & & \\
\hline Crangon crangon & 3 & & & 1 & & & & & \\
\hline Chironomid sp. & & & & 1 & & & & & \\
\hline Potamopyrgus antipodarum & & & & 1 & & & & & \\
\hline Limecola balthica & & & & 1 & 1 & & & & \\
\hline Total abundance & 945 & 7 & 1 & 703 & 370 & 329 & 5 & $\mathbf{0}$ & $\mathbf{0}$ \\
\hline
\end{tabular}

Table 1. Upper Clyde Estuary Survey, 2016. Faunal abundance (number of individuals) per $0.1 \mathrm{~m}^{2}$ grab. 

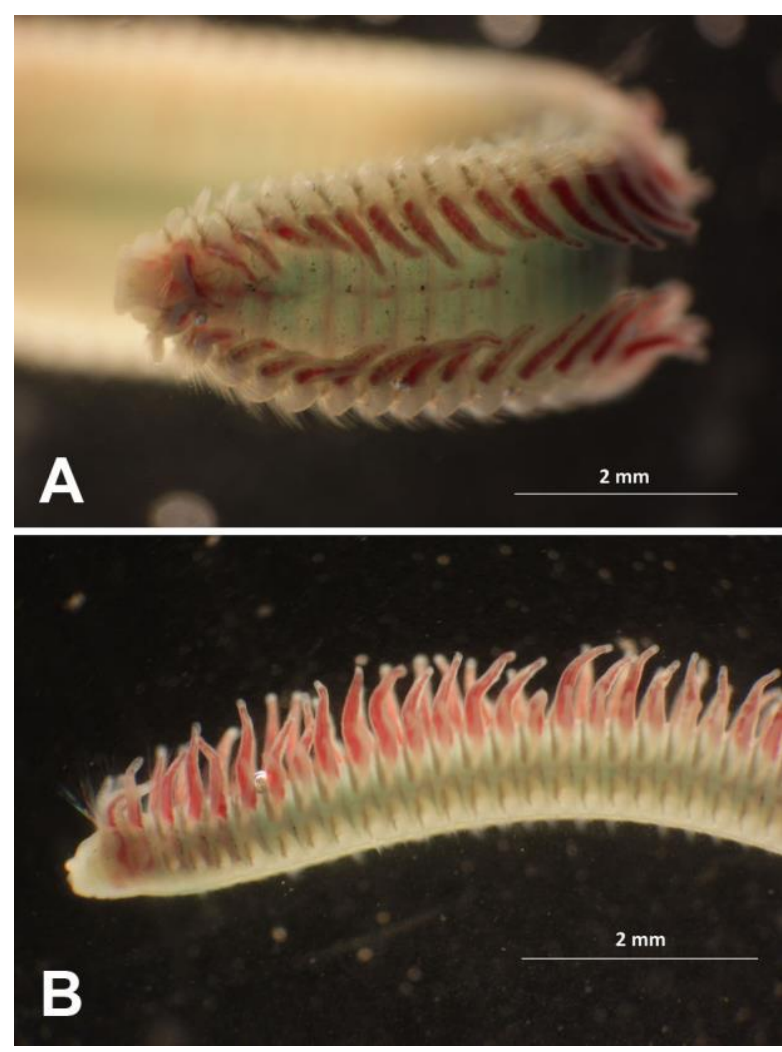

Fig. 1. Green palpworm (Marenzelleria viridis) from the upper Clyde Estuary. (A) Dorsal view of the anterior end, showing red gills and pale green body. Note that the feeding palps have been shed. (B) Lateral view of the anterior end of another specimen (also lacking the feeding palps). (Photos: M. O'Reilly)

Further sampling was undertaken at Govan Wharf on 15th November 2017 to find new specimens of $M$. viridis for photography and to re-assess its abundance. Two more $0.1 \mathrm{~m}^{2}$ Day Grabs were collected and $M$. viridis was sorted live from the samples, which recovered 100 and 126 specimens respectively. The $M$. viridis were returned to the laboratory for fixing, counting and imaging. The imaging of $M$. viridis was undertaken on material freshly fixed with formaldehyde with the aid of a phototube on an Olympus SZX12 stereo microscope. The mean abundance of $M$. viridis for 2016 and 2017 sampling at Govan Wharf was 133 per grab giving an average density of $1,330 \mathrm{~m}^{-2}$. Although oligochaetes are numerically more abundant at this location, they are much smaller than $M$. viridis, which dominated the faunal biomass. For example, the wetblotted biomass for all macrofauna per grab in September and December 2016 was 1.81 and $6.63 \mathrm{~g}$ respectively, of which $M$. viridis comprised $75 \%$ and $96 \%$ by wet weight.

\section{DISCUSSION}

The upper Clyde Estuary has been monitored intensively on an annual basis from 1974 to 1995 by the Clyde River Purification Board including sites relatively close to Govan Wharf at the Broomielaw ("0 km"), the Kelvin confluence ("3.2 km"), and King George V Dock ("6.4 km") (see Henderson, 1984). From 1996 the monitoring was continued by SEPA, though less frequently with surveys every third year up until 2010. The fauna at these sites, where the salinity ranges from 0 - 17 psu, has always been dominated by small oligochaetes and fewer polychaetes but no $M$. viridis was ever recorded previously.

Although the 2016 survey fauna showed some depletion over the sampling period, the decline preceded the planned sewerage discharges (which occurred in October and November) and these changes were attributed to natural perturbations. The fauna found in 2016 was typical for these waters, except for the occurrence of $M$. viridis.

The appearance of $M$. viridis in the Clyde was unexpected but it seems to have become well established at Govan Wharf. M. viridis appears to have gradually spread around the estuaries of the British mainland but there are few records on the western seaboard and, until now, none in western Scotland. The nearest colonised sites are in the estuaries of the Foyle and Bann in Northern Ireland where it arrived in the late 1990s. It is believed that it is spread by transport of planktonic larvae in ballast waters of marine vessels so could well have spread from any other site around the U.K. or elsewhere depending on vessel movements. The Clyde population of $M$. viridis could in turn enable its spread to other areas although no studies of its reproduction, or dispersal of planktonic larvae, have been undertaken in this vicinity. It seems likely that $M$. viridis will maintain its presence in the Clyde Estuary as it has done in the Forth Estuary. It is just one of many non-native species which have become established in marine waters of the U.K. (Eno et al., 1997). It is regarded as having low ecological impact in U.K. waters with respect to classification under the EU Water Framework Directive (UKTAG, 2015). However, its congener, M. neglecta, has had a significant ecological impact in the Baltic Sea and may possibly spread to U.K. waters (GB NNSS, 2011).

\section{REFERENCES}

Atkins, S.M., Jones, A.M. \& Garwood, P.R. (1987). The ecology and reproductive cycle of a population of Marenzelleria viridis (Annelida: Polychaeta: Spionidae) in the Tay Estuary. Proceedings of the Royal Society of Edinburgh 92B, 311-322. https://doi.org/10.1017/S0269727000004735

Bastrop, R. \& Blank, M. (2006). Multiple invasions - a polychaete genus enters the Baltic Sea. Biological Invasions 8, 1195-1200. https://doi.org/10.1007/s10530-005-6186-6

Bastrop, R., Röhner, M. \& Jürss, K. (1995). Are there two species of the polychaete genus Marenzelleria in Europe? Marine Biology 121, 509-516. https://doi.org/10.1007/BF00349460

Bick, A. (2005). A new Spionidae (Polychaeta) from North Carolina, and a redescription of Marenzelleria wireni Augener, 1913, from Spitsbergen, with a key for all species of Marenzelleria. Helgoland Marine Research 59, 265-272. https://doi.org/10.1007/s10152-005-0002-7

Elliott, M. \& Kingston, P.F. (1987). The sublittoral benthic fauna of the estuary and Firth of Forth, 
Scotland. Proceedings of the Royal Society of Edinburgh 93B, 449-466. https://doi.org/10.1017/S0269727000006874

Eno, N.C., Clark, R.A. \& Sanderson, W.G. (Editors). (1997). Non-native Marine Species in British Waters: a Review and Directory. Joint Nature Conservation Committee, Peterborough.

Essink, K. \& Kleef, H.L. (1993). Distribution and life cycle of the North American spionid polychaete Marenzelleria viridis (Verrill, 1873) in the Ems Estuary. Netherlands Journal of Aquatic Ecology 27, 237-246. https://doi.org/10.1007/BF02334787

Fauchald, K. (1977). The polychaete worms. Definitions and keys to the Orders, Families and Genera. Natural History Museum of Los Angeles County, Science Series 28, 1-190.

GB NNSS (2011). Factsheet. Red-gilled mudworm, Marenzelleria neglecta. GB Non-native Species Secretariat. (Online: accessed 23.1.2019), http://www.nonnativespecies.org/factsheet/downloa dFactsheet.cfm?speciesId=3797

Gruszka, P. (1991). Marenzelleria viridis (Verrill, 1873) (Polychaeta: Spionidae) - a new component of shallow water benthic community in the southern Baltic. Acta Ichthyologica et Piscatoria 21 (Suppl.), 57-65. https://doi.org/10.3750/AIP1991.21.S.07

Hayward, P.J. \& Ryland, J.S. (2107). Handbook of the Marine Fauna of North-west Europe. (2nd edition). Oxford University Press, Oxford.

Henderson, A.R. (1984). Long term monitoring of the macrobenthos of the upper Clyde Estuary. Water Science and Technology 16, 359-373. https://doi.org/10.2166/wst.1984.0143

Kotta, J., Orav-Kotta, H., Kotta, I. \& Simm, M. (2003). Effect of the introduced polychaete Marenzelleria viridis on the simple ecosystem of the northern Baltic Sea. Theme Session P. Physical-Biological Interactions in marginal and Shelf Seas. ICES Council Meeting documents, Copenhagen, ICES CM 2003/P:09, pp. 1-43. (Online: accessed 23.1.2019), https://doi.org/10.1007/s10152-006-0027-6

Kotta, J., Kotta, I., Simm, M., Lankov, A., Lauringson, V., Põllumäe, A. \& Ojaveer, H. (2006). Ecological consequences of biological invasions: three invertebrate case studies in the north-eastern Baltic Sea. Helgoland Marine Research 60, 106-112.

Kube, J., Zettler, M.L., Gosselck, F., Ossig, S. \& Powilleit, M. (1996). Distribution of Marenzelleria viridis (Polychaeta: Spionidae) in the southwestern Baltic Sea in 1993/94 - ten years after introduction. Sarsia 81, 131-142.

Maciolek, N. J. (1984). New records and species of Marenzelleria Mesnil and Scolecolepides Ehlers (Polychaeta; Spionidae) from Northeastern North America. In: Hutchings, P.A. (Editor). Proceedings of the First International Polychaete Conference, Sydney, pp. 48-62. Linnean Society of New South Wales.

Maximov, A.A. (2011). Large-scale invasion of Marenzelleria spp. (Polychaeta; Spionidae) in the eastern Gulf of Finland, Baltic Sea. Russian Journal of Biological Invasions 2, 11-19.

https://doi.org/10.1134/S2075111711010036

McLusky, D.S., Hull, S.C. \& Elliott, M. (1993). Variations in the intertidal and subtidal macrofauna and sediments along a salinity gradient in the upper Forth estuary. Netherlands Journal of Aquatic Ecology 27, 101-109. https://doi.org/10.1007/BF02334773

Michalek, M. \& Werner, M. (2012). Abundance and Distribution of Marenzelleria Species in the Baltic Sea. HELCOM Baltic Sea Environment Fact Sheets. (Online: $\quad$ accessed 11.1.2019), http://www.helcom.fi/baltic-seatrends//environment-fact-sheets/.

National Biodiversity Network (2019). National Biodiversity Network Atlas. (Online: accessed 23.1.2019) https://species.nbnatlas.org/

Sikorski, A.V. \& Bick, A. (2004). Revision of Marenzelleria Mesnil, 1896 (Spionidae, Polychaeta). Sarsia 89, 1-24. https://doi.org/10.1080/00364820410002460

Syomin, V., Sikorski, A., Bastrop, R., Köhler, N., Stradomsky, B., Fomina, E. \& Matishov, D. (2017). The invasion of the genus Marenzelleria (Polychaeta: Spionidae) into the Don River mouth and the Taganrog Bay: morphological and genetic study. Journal of the Marine Biological Association of the United Kingdom 97, 975-984. https://doi.org/10.1017/S0025315417001114

UK TAG (2015). Revised Classification of Aquatic Alien Species According to their Level of Impact. U.K. Technical Advisory Group on the Water Framework Directive. (Online: accessed 23.01.2019),

https://www.wfduk.org/sites/default/files/Media/As sessing $\% 20$ the $\% 20$ status $\% 20$ of $\% 20$ the $\% 20$ water $\%$ 20environment/UKTAG\%20classification $\% 20$ of $\%$ 20alien\%20species\%20working\%20paper\%20v7.6. pdf

Van Moorsel, G., Tempelman, D. \& Lewisde, W. (2010). De Oostzeegroenworm Marenzelleria neglecta in het Noordzeekanaal (Polychaeta: Spionidae). Nederlandse Faunistische Mededelingen 34, 45-54. 